\title{
THE SIMILARITY OF THE MEDINA CHARTER AND THE INDONESIAN CONSTITUTION IN HUMAN RIGHT'S PROTECTION
}

\author{
Faiq Tobroni \\ Faculty of Sharia and Law, UIN Sunan Kalijaga Yogyakarta \\ Email: faiq.tobroni@uin-suka.ac.id
}

\begin{abstract}
The movement that wants to make an Islamic constitution still threatens Indonesia. This movement is exacerbated by the misunderstanding that the Medina Charter was proof of the obligation for Muslims to establish an Islamic state as was done by the Prophet Muhammad. In fact, the Medina Charter regulates more about the protection of human rights (HAM) for every citizen regardless of religious background.This study aims to examine the position of the Medina charter as an argument for the establishment of the state and the similarity between the Indonesian constitution and the spirit of protecting human rights in the Medina charter. This research is a literature review by examining classical and modern references relevant to the establishment of the state and the Medina Charter. The finding in this research is that the Medina charter is a legal product at the time of the Prophet Muhammad (pbuh). Muslims are not obliged to establish a form of Islamic State and a constitution that is exactly the same as what was done by the Prophet Muhammad (pbuh). In substance, the Medina Charter is a symbol of peace, tolerance and moderation. Thus, philosophically, the spirit of the Medina charter has been embodied in the Indonesian constitution which has prioritized the peace and welfare of the people. The implication of this finding is that there is no necessity for the establishment of an Islamic State. Without declaring an Islamic constitution, the 1945 Constitution accommodates the spirit of protecting human rights which is in line with the Medina charter.

Gerakan yang ingin membuat konstitusi Islam masih mengancam negara Indonesia. Gerakan ini diperparah dengan kesalahan memahami bahwa Piagam Madinah sebagai bukti keharusan umat Islam mendirikan negara Islam sebagaimana dilakukan Nabi Muhammad. Kenyataannya Piagam Madinah lebih dominan mengatur tentang perlindungan Hak Asasi Manusia (HAM) bagi setiap warga negara tanpa membedakan latar belakang agama. Penelitian ini bertujuan mengkaji kedudukan piagam Madinah sebagai argumentasi pembentukan negara dan bentuk kemiripan konstitusi Indonesia dengan semangat perlindungan HAM dalam piagam Madinah. Penelitian ini merupakan kajian kepustakaan dengan menelaah refrensi klasik dan modern yang relevan dengan pembentukan Negara dan piagam Madinah. Temuan dalam penelitian ini bahwa piagam Madinah
\end{abstract}


termasuk produk hukum di masa Nabi Muhammad saw. Umat Islam tidak wajib membuat bentuk Negara Islam dan bentuk konstitusi yang sama persis dengan apa yang telah dilakukan Nabi Muhammad. Pada subtansinya piagam Madinah adalah simbol perdamaian, tolerasi, dan moderasi. Maka secara filosofis semangat piagam Madinah telah tertuang di dalam konstitusi Indonesia yang telah mengedepannkan kedamaian dan kesejahteraan rakyat. Implikasi dari temuan ini bahwa tidak ada kemestian pembentukan Negara Islam, tanpa mendeklarasikan konstitusi Islam, di dalam Undang-Undang Dasar tahun 1945 yang telah mengakomodasi semangat perlindungan HAM yang sejalan dengan piagam Madinah.

Keywords: The Medina Charter; Human rights; Indonesian Constitution.

\section{INTRODUCTION}

The desire to formalize Islamic law often appears in Indonesia. There are at least five forms for realizing this agenda. The first pattern is to make basic laws regarding essential civilization, such as divorce, inheritance, hajj, etc. Indonesia itself has implemented the first stage through the Marriage Law and other regulations. The second pattern is by creating special institutions regarding Islamic economics such as zakat bodies, waqaf bodies, and so on. The third pattern is by making regional regulations with sharia nuances that regulate religious rites, such as Muslim clothing, anti-alcoholism, compulsory reading of the Koran, and so on. The fourth pattern makes Islamic criminal law, such as the Aceh Qanun. The fifth pattern is implementing the Islamic caliphate concept and changing the 1945 Constitution. The first to the fourth patterns have occurred. What is still being debated is the third pattern. Meanwhile, the fifth pattern has not yet occurred but there are indications of movement towards the target. Even so, the government has anticipated with the dissolution of Hizbut Tahrir Indonesia. Therefore, in addition to political efforts in the form of government legal policies, the campaign against the replacement of the 1945 Constitution with the Islamic Constitution can be carried out with scientific studies, including realigning the existence of the Medina Charter which is often misunderstood as an Islamic teaching that must be carried out by every Muslim. The following research would like to show that the Medina Charter is not a mandatory religious law, in fact its existence is a social agreement document containing human rights protection for all religious adherents. Even without having to say that it applies the Islamic Constitution, in fact the 1945 Constitution has implemented the spirit of protecting human rights as stipulated in the Medina Charter. Therefore, Indonesia does not need to replace the 1945 Constitution with an Islamic Constitution. 
The Prophet Muhammad introduced the First Constitution in the world, the Medina Charter. This charter is a joint agreement that was built by Muslims with other religious communities. In a modern context, the Medina Charter can be compared as the Constitution of a country that regulates relations between citizens. However, today the Medina Charter is often misunderstood as the first miniature establishment of an Islamic state because its maker was the Prophet Muhammad. That is why, today nostalgia for establishing an Islamic state is still alive. Efforts to formalize the legislations based on shariahin the Indonesian context never stop. This can be indicated by the acts of legislators both in the national and in the firsttier regions (the provinces) as well as the second-tier regions (districts); be it in the form of shari'ah-based constitution, Islamic legislations, or even shari'ah-nuanced regional regulations (Peraturan Daerah bernuansa syari'ah). These efforts are not easy to stop because it is based by the religious thought and the historical experience. The strugle to realize the constitution and legislations based on shari'ah is done by groups of Muslim society. What they relied on is the interpretating way to religious texts. For this group, they believe that the formalization of the constitution/legislation based on shari'ahwas done by the Prophet in the form of the Madina Charter. Due to the Prophet did himself, it is included into legal sunnah (sunnah shar'iyyah). Because formalization of legislation based on shari'ah was done by Muhammad, therefore, according to them, is a part of Muslim obligations torealize the formalization of shari'ahto adhere the Prophetic sunnah.

But on the other hand, in fact the Medina Charter does not regulate religious worship at all. The Medina Charter actually regulates the relation of how to protect citizens (the rights of every citizen). Even the protection provided by the Medina Charter to every citizen does not distinguish between religious backgrounds. That is why to align the position of the Medina Charter as the spirit of modern human rights today to protect every citizen regardless of religious background, the author wants to offer a perspective on how to understand every action taken by the Prophet Muhamamd. The Medina Charter as a form of agreement made by the Prophet Muhammad must be read proportionally so that its existence is not precisely to construct concepts as if the Medina Charter is only used to protect Muslims. Changes in the way of reading is using the method of reading the concept of sunnah shar'iyyah from Hashim Kamali. Quoting Hashim Kamali's view, legal sunnah (sunnah shar'iyyah) is devided into three types. Firstly, sunnah in the Prophetic capacity as a Messenger of God. Secondly, sunnah in the Prophetic capacity as a imam or head of state. Thirdly, sunnah in the Prophetic capacity as a judge (qadi). This is the methodology of ijtihad I am using to rethink the legality (mashru'iyyah) of the Prophetic acts to formalize the Medinah Charter. 
By knowing the position of the Medina Charter in the sunnah shar'iyyah discourse, this is intended to free the burden of the Medina Charter which has often been misused as a proposition for every Muslim's obligation to establish an Islamic state. By knowing the position of the Medina Charter in the sunnah shar'iyyah discourse, this is intended to build a new view that the existence of the Medina Charter is evidence of the obligation of every Muslim to establish a state that protects human rights for every citizen without distinguishing religious backgrounds. This paper is the result of research using qualitative methods. Qualitative data that has been obtained is the concept offered by Hashim Kamali about how should understand what has been done by the Prophet Muhammad, and how to respond to the actions of the Prophet Muhammad what is worthy of sunnah shar'iyyah. After that, the qualitative data is processed to be narrated as an analysis of how the actual human rights values contained in the Medina Charter can be used as a justification to strengthen human rights in the Indonesian Constitution.In this paper, the principle questions are as follows: how is the position of the Medina Charter seen from the concept of sunnah shar'iyyah? and what message can be transformed for the Indonesian Constitution?

\section{DISCUSSION}

\section{A. The Madina Charter as Legal-Sunnah (Sunnah Shar'iyyah)}

As Kamali wrote, the entire bulk of the sunnah, that is, the sayings, acts and tacit enactments of the Prophet, may once again be devided into two types: nonlegal and legal sunnah. Non-legal sunnah (sunnah ghayr tashri'iyyah)does not seek to constitute a part of shari'ah. The Prophet did it in his capacity as normal person. It mainly consists of the natural activities of the Prophet (al-af'al al-jibilliyah) such as the manner in which he ate, slept, dressed, and such other activities. ${ }^{1}$ These, according to the majority, do not constitute legal norms. Activities of this nature, therefore, are not of primary importance to the Prophetic mission. Muslims must not lay down the Prophet's preferences in the areas, such as his favourite colours, or the fact that he slept on his right side in the first place, etc., as legal norms, as Shaltut maintained, because they only indicate the premissibility (ibahah) of the acts in question. ${ }^{2}$

The non-legal sunnah consists of the natural activities of the Prophet, whereas the legal sunnah (sunnah tashri'iyyah) consists of the exemplary conduct of

\footnotetext{
${ }^{1}$ Mohammad Hashim Kamali, Principles of Islamic Jurisprudence (Cambridge: The Islamic Texts Society, 2003), p. 67.

${ }^{2}$ Muhammad Hahim Kamali, Principles,...p. 67. See also 'Abd al-Wahhab Khallaf, 'Ilm Usul al-Fiqh. 12th edition, (Kuwait: Dar al-Qalam, 1978), p. 43.
} 
the Prophet, be it an act, saying, or a tacit approval, which incorporates the rules and principles of shari'ah. This variety of sunnah is not only a single one, but also may be devided into three types, namely the sunnah in the capacities of the Prophet as Massenger of God, as the head of state or imam, or a judge. ${ }^{3}$ Hashim Kamali will discuss each of these separately, as follows.

1. All the rulings of sunnah which originate from the Prophet in his capacity as Messenger of God, the rules are not only complementary to the Qur'an, but also established rules on which the Qur'an is silent. In this capacity, the sunnah may consist of a clarification (tabyin) of the ambiguous (mujmal) parts of the Qur'an, or specifying (takhsis) the general ('amm) messeges of the Qur'an, and qualifying (taqyid) the abolute (muthlaq) contents of the Qur'an. Whatever the Prophet has authorised pertaining to the principles of religion establishes general legislation (tashri' amm). What the Prophet has laid down as legal norms is especially in the area of devotional matters ('ibadat) and rules expounding the lawfull (halal) and the unlawfull (haram) whose validity is not restricted by the limitations of time and circumstance. All commands and prohibitions that are imposed by the sunnah are, as Kamali Wrote, binding on every Muslim regardless of individual circumstances, social status, or political office. In acting upon these laws, as Kamali quoted Shaltut, the individual normally does not need any prior authorisation by a religious leader or the government. ${ }^{4}$

2. In his capacity as imam or head of state, the Prophet has laid down the examplary conducts such as the allocation and expenditure of public funds, decisions pertaining to military strategy and war, appointment of state officials, distribution of booty, signing of treaties, etc., are parts of the legal sunnah which, however, does not constitute general legislation (tashri' 'amm). These still consist of legal norms but do not bind on every Muslim. Sunnah of this type is not pertaining to the principles of religion and just for government matters. It may not be practised by individuals without obtaining the permission of competent government authorities first. The mere fact that the Prophet acted in a certain way, or said something relating to these matters, does not bind individuals directly, and does not entitle them to act on their own initiative without the express permission of rhe lawful authority. ${ }^{5}$

3. Sunnah which originates from the prophet in his capacity as a judge in particular disputes usually, as Kamali wrote, consists of two parts: the part which relates to

${ }^{3}$ Muhammad Hahim Kamali, Principles,...p. 69.

${ }^{4}$ Muhammad Shaltut, al-Islam, 'Aqidah wa Shari'ah (Kuwait: Matabi Dar al-Qalam, 1966), p.

513.

${ }^{5}$ Muhammad Hahim Kamali, Principles,...p. 71. 
claims, evidence, and factual proof, and the judgement which is issued as a result. The first part is situational and does not constitute general law (tasyri' 'amm), whereas the second part lays down general law (tasyri' 'amm) with the provision. ${ }^{6}$ There is a provision to lay down the second part as general legislation, namely it does not bind the individual directly. Based on the requirement, no one may act upon it without the prior authorisation of a competent judge. Since the Prophet himself acted in a judicial capacity, the rules that he has enacted, as Kamali quoted Shawkani, must therefore be implemented by the office of the qadi. ${ }^{\text {? }}$

From this categorization of sunnah, one may conclude that the Prophetic act to authorize the Madina Charter is a part of legal sunnah (sunnah syar'iyyah) in the capacity as a imam or head of state. This is caused that he acted in the purpose of governing the plurality of Madina People, be it in religious, tribe or even interest. The agreement between Muhajirin and Anshar, and the contract between the Muslims and the Jews formally were writen in the manuscript called as a (shahifah) charter, or in the other words called as a document. ${ }^{8}$ The charter (shahifah), as regarded by some experts both from Muslims and non-Muslims, had named by historian as the constitution of Madina, aggreement, treaty, charter, etc.Muslims do not need, therefore, to follow similarly as the Prophet did, especially authorizing the constitution based on shari'ah. In the Indonesian context, authorizing constituion based on shari'ah need to the permission of authorized government, namely People's Representative Council and People's Consultative Assembly (DPR/MPR) as Indonesian people representatives. What the Indonesian founding fathers have done by authorizing the constitution not based on Shari'ah is not at odds with legal sunnah (sunnah syar'iyyah) or the examplery conduct of people.

The constitution in Muslim society does not need to formulize the shari'ah identity. It can only articulate the spirit of shari'ah. Although Indonesia is known Muslim people in majority, the numeral majority should not neglect the numerical minority. It is necessary to note that a representative government based on universal suffrage is a necessary but should not tyrany. As recent history has clearly shown, as an-Na'im quoted Wheare, universal suffrage can create and support tyrany of the majority or of a minority or of even one man. ${ }^{9}$ It is therefore important to emphasize that the government must be controlled by more fundamental

${ }^{6}$ Muhammad Hahim Kamali, Principles... p. 73

${ }^{7}$ Yahya al-Shawkani, Irshad al-Fuhul min Tahqiq al-Haqq ila 'Ilm al-Usul (Cairo: Dar al-Fikhr, n.d), p. 36.

${ }^{8}$ A. Guillaume, The Life of Muhammad, translation ofSirah Rasul Allah (Pakistan: Pakistan branch of Oxford University Press, 1970), p. 232.

${ }^{9}$ K. C. Wheare, Modern Constitutions (London: Oxford University Press, 1966), p. 139. 
principles. One of these principes is equality. It consists of the universal rule that one should treat others as he or she wishes to be treated by them. According to Mcllwain as quoted by An-Na'im, the government should invalidate any legislative and executive action that is inconsistent with those principles for the sake of guaranting the real human rights. ${ }^{10}$ What is important here is the principle of protecting the rights of whoever is subjected to or threatened with oppression or discrimination, be it a majority, a minority, or a single person. ${ }^{11}$ The government and its power and wealth is the mandate of Allah and the Muslims, which must be handled by the believers, to be fair and right. ${ }^{12}$

\section{B. Similar Spirit of Human Rights Protection in The Medina Charter and The Indonesian Constitution}

The position of the Medina Charter is actually more phenomenal with the constitution now known in the West. The Medina Charter is the first written charter in the history of mankind which could have been more phonemenal compared to the understanding of the constitution in the modern sense. This charter was made with mutual agreement between the Prophet Muhammad as a representative of Muslims with several tribes as residents of the city of Medina. In terms of naming, experts call the Medina Charter with a variety of terms that differ from one another. ${ }^{13}$

Montgomery Watt uses the terms The Constitution of Medina ${ }^{14}$ and Zainal Abidin Ahmad to use the Charter as a translation of the word al-shahifah. ${ }^{15}$ The name al-shahifah of $622 \mathrm{AD}$ is the name mentioned in the charter text itself. ${ }^{16}$ This word is even mentioned eight times in the text of the charter. The difference in terms cannot be separated from the point of view used by each writer. For example,

${ }^{10}$ C.H. Mcllwain, Constitutionalism Ancient and Modern (Ithaca: Cornel University Press, 1947), p. 37-38.

${ }^{11}$ Abdullah Ahmad an-Na'im, Toward and Islamic Reformation (New York: Syracuse University Press, 1990), p. 72.

${ }^{12}$ Hamzah and Samiang Katu. "Pemikiran Islam tentang Hubungan Negara dengan Agama." Dirasat Islamiah: Jurnal Kajian Keislaman 1.1 (2020), p. 66.

${ }^{13}$ Ahmad Sukardja, Piagam Madinah dan Undang-Undang Dasar 1945: Kajian Perbandingan tentang Dasar Hidup Bersama dalam Masyarakat Majemuk, (Jakarta: UI-Press, 1995); DahlanThaibet al., Teori Konstitusi dan Hukum Konstitusi, $5^{\text {th }}$ Ed., (Jakarta: PT RajaGrafindoPersada, 2005). See alsoTahir Azhary, Negara Hukum: Suatu Studi tentang Prinsio-prinsipnya Dilihat dari Segi Hukum Islam, Implementasinya pada Periode Negara Madinah dan Masa Kini,2 ${ }^{\text {nd }}$ Ed., (Jakarta: Kencana, 2004).

${ }^{14} \mathrm{~A}$ Montgomery Watt, Muhammad: Prophet and Statesman, (New York: Oxford University Press, 1964), p. 93.

${ }^{15}$ Zainal Abidin Ahmad,Piagam Nabi Muhammad SAW: Konstitusi Negara Tertulis yang Pertama di Dunia, (Jakarta: Bulan Bintang, 1973).

${ }^{16}$ Ahmad Sukardja, Piagam Madinah dan Undang-Undang Dasar 1945: Kajian Perbandingan tentang Dasar Hidup...p. 2. 
in looking at the position of the Medina Charter, Watt emphasized the legal implications more than Zainal Abidin which focused more on religious products. The formation of the constitution can be through a decision (decree) that is 'gift' or 'grand' from a ruler, or prepared by an agency/committee, or formed by a special institution whose authorizations to make it. ${ }^{17}$ In this formalistic sense, a constitution has been defined as "the organic and fundamental law of a nation or state; establishing the character and conception of its government; organizing such government, and regulating, distributing, and limiting the functions of its different departments, and prescribing the extent and manner of the exercise of sovereign powers" ${ }^{18}$ In the course of time, it came to be realized that to avoid the dangers of the corruption and the abuse of power and to ensure that the powers of government were properly employed to achieve their legitimite objectives and their prescribed methods, the structure and functioning of government must be regulated by clearly defined and strictly applied rules. This body of rules, as enacted and applied within the context of a given state, is called the constitution of that particular state. ${ }^{19}$

The function of the constitution is to formulate the principle that public authority is to be exercised according to law. The state and civic institutions have their legitimation in a constitution. Similarly, the executive and legislative powers have their source in a constitution. In short, it will establish a government of law and not of men (rule of law and not rule of men, in other words rechtstaat and not machstaat). ${ }^{20}$ In light of this crucial purpose, it is imperative for every nation-state to assess any given constitution, according to its ability, to achieve the proper balances between individual liberty and social justice in the context of the modern nationstate. In particular, the modern nation-state, like Indonesia, should be predicated on the principle of the equality of all its citizens before the law ${ }^{21}$, whitout discrimination on grounds such as race, color, gender, language, religion, or political or other opinion. The Indonesian constitution has been designed to achieve them.

It can be understood that constitution should protect human rights fotevery group of citizens. The implication is that the nation-state is the normal and valid arena for the pursuit of liberty and justice. Most importantly a direct consequnce of

${ }^{17}$ Miriam Budiardjo, Dasar-dasar Ilmu Politik (Jakarta: PT. Gramedia Pustaka Utama, 1991), p. $95-102$.

${ }^{18}$ Henry C. Black, Black's Law Dictionary, 5th ed. (St. Paul: West Publishing, 1979), p. 282.

${ }^{19}$ Abdullah Ahmad an-Na'im, Toward,..., p. 70.

${ }^{20}$ Abdullah Ahmad an-Na'im, Toward,..., p. 70.

${ }^{21}$ Moh. Mahfudz MD, Membangun Politik Hukum, Menegakkan Konstitusi (Jakarta: LP3ES, 2006), p. 15. 
formulating constitutionalism is to protect and fulfill human rights. Without constitutionalism, there can be little hope for the respect of human rights. Indeed even autocratic and dictatorial regimes include a bill of rights in their constitution. But since of their practice of government is not based on respect of individual autonomy, human rights are a frequent casualty in such systems. Briefly put, the establishment of constitutionalism is a precondition for the enjoyment of human rights. ${ }^{22}$ The Constitution in even Muslim society, according to An-Na'im, merely provides the framework, institutions, and mechanisms for the constant mediation and resolution of the outstanding issues within the context of a given nation state. The Prophet had left the examplery constitution in theMadina Charter, which consists of the universal principles of respecting the human rights, equality, plurality and brotherhood.Because of that, the constitution can always change based on the need of certain citizens. In anticipation of the need for adjusting and adapting in response to changing circumstances, it is always necessary to provide some mechanism or procedure for amending the constitution. Provided that the amendment mechanism or procedure is satisfied from formal point of view, the constitution can be lawfully changed, even if the amendment repudiates the most fundamental aspects of constitutionalism. ${ }^{23}$ Viewed from the aspect of linguistics, in the Indonesian 1945 Constitution and the Medina Charter, there aresome similarness, namelythere are clear words that mean the spirit of human rights and nationalism. From the analysis, it can be drawn in general principles as follows.

Monoteisme. Inthe Medina Charter, the concept ofTawhid(Tauhid) is contained inMukadimah"This is a document from Muhammad the Prophet (may Allah bless him and grant him peace), governing relations between the Believers i.e. Muslims of Quraysh and Yathrib and those who followed them and worked hard with them".In the Indonesian 1945 Constitution, the concept of monotheism is contained in the first principle of the Pancasila"The belief in One God", Article 9 "Before assuming office, the President and the Vice-President shall take the oath of office according to their religions...." and Article 29 "The state shall be based upon the belief in the One and Only God".

Unity and Integrity. The spirits of unity and integrity in the Medina Charter are defined in Article 1"They form one nation - Ummah", 15 "Believers are all friends to each other to the exclusion of all others" and 25 "The Jews of Bani Awf will be treated as one community with the Believers. The Jews have their religion. This will also apply to their freedmen. The exception will be those who act

${ }^{22}$ Ishtiaq Ahmed, "Abdullah Ahmad an-Na'im on Constitutional and Human Rights Issues, (ed) Tore Lindholm and Kari Vogt, IslamicLaw Reform and Human Rights (Oslo: the Norwegian Institute of Human Rights, 1993), p. 62.

${ }^{23}$ Abdullah Ahmad an-Na'im, Toward,..., p. 72. 
unjustly and sinfully. By so doing they wrong themselves and their families". In the 1945 Constitution, it was mentioned in the third principle of Pancasila "The unity of Indonesia", Article 1 (1) "The state of Indonesia is a Unitary state which has the form of a Republic".

Equality and Justice. These concepts are acomodated in the Medina Charter of Article 13 "The Believers, who fear Allah, will oppose the rebellious elements and those that encourage injustice or sin, or enmity or corruption among Believers. If anyone is guilty of any such act all the Believers will oppose him even if he be the son of any one of them"; Article 16 "Those Jews who follow the Believers will be helped and will be treated with equality. Social, legal and economic equality is promised to all loyal citizens of the State"; Article 24 "The Jews will contribute towards the war when fighting alongside the Believers"; Article 37 "The Jews must bear their own expenses (in War) and the Muslims bear their expenses". The concepts of equality and justice in the 1945 Constitution are contained in the fifth principle of Pancasila“The realization of social justice for all of the people of Indonesia; the Constitution of Article 27 "(1) All citizens have equal status before the law and in government and shall abide by the law and the government whitout any exception, (2) Every citizen has the right to work and to live in human dignity"; $28 \mathrm{H}$ "(2) Each person has the right to assistance and special treatment in order to gain the same opportunities and benefits in the attainment of equality and justice"; 33 "(4) The national economy is organized based on economic democracy and the principles of togetherness, efficiency of justice, sustainability, enviromental awareness, self-sufficiency and by safeguarding the equilibrium between progress and the unity of the national economy".

Religious Freedom. Religious freedom is referred to in Article 25 of the Medina Charter "The Jews of Bani Awf will be treated as one community with the Believers. The Jews have their religion. This will also apply to their freedoom”. In the 1945 Constitution, religious freedom is referred to in Article 28E "(1) Each person is free to profess their religion and to worship in accordance with their religion....."; 28I "(1) .....the right to freedom of thought and conscience...........are basic human rights that may not be interfered with under any circumstances at all..."; 29 "(2) the state guarantees all persons freedom of religion and freedom to worship according to their religion and belief".

Defending State. It is explicit and implicit in Article 24 of the Medina Charter "The Jews will contribute towards the war when fighting alongside the Believers"; 37 "The Jews must bear their own expenses (in War) and the Muslims bear their expenses"; 44 "Yathrib will be Sanctuary for the people of this Pact".The 1945 Constitution accomodate it in Article 27 "(3) Every citizen has the right and 
duty to participate in the defense of the nation"; and Article 30 "(1) Each citizen has the right and duty to participate in national defense and security".

The spirit brought by the Medina Charter actually shows the spirit of protecting human rights for every citizen regardless of religious background. All citizens who submit to the Medina Charter will receive protection from the Prophet Muhammad. That is why it can be said that although the Medina Charter includes the Sunnah Shar'iyyah, the rules it carries are not in order to force the establishment of an Islamic state. The rules in the Medina Charter precisely direct the obligation to the state to protect the human rights of every citizen without regard to religious differences. Thus, what needs to be taken from the Medina Charter for the Indonesian Constitution is not the spirit of establishing an Islamic state, but what needs to be taken is the spirit of protecting the human rights of every citizen.

The spirit of human rights protection brought by the Medina Charter is the protection of human rights carried out in the spirit of maintaining the unity of a country. In some provisions, for example, the Medina Charter emphasizes the importance of the unity and unity of Muslims with non-Muslims, and even the unity of Muslims from the Muhajirin and the Anshor. From the beginning, the Medina Charter has also faced the fact of plurality in society. The spirit of human rights protection in the Medina Charter is also applied in the Indonesian Constitution. For example, the Indonesian Constitution strongly emphasizes unity. In addition to emphasizing unity, the Indonesian Constitution also requires citizens to defend the country. Specifically, regarding unity, the spirit in the Indonesian Constitution is also similar to the challenges faced by the Medina Charter, namely unity of diverse societies. The Indonesian Constitution also emphasizes the importance of the awareness of each Individual to maintain the unity and integrity of the state at every opportunity to enjoy their rights. These signs can be seen in the provisions of Article 28J paragraph (2) of the 1945 Constitution which states that the implementation of human rights must pay attention to national order and security.

In connection with this analysis, it can be concluded that the Medina Charter is actually a concrete example of the Prophet's valuable Sunnah Shar'iyyah practices in the capacity of the Prophet as head of state. As Muslims, Indonesian Muslims are indeed required to follow all the Sunnah Shar'iyyah that has been taught by the Prophet Muhammad. But in the context of the Medina Charter, the obedience needed to implement the Medina Charter is not in the form of establishing an Islamic state, but rather must be realized by transforming the spirit of protection of every citizen of human rights without discriminating in religious backgrounds. This spirit must be incorporated into the Indonesian Constitution. 


\section{CONCLUSION}

The Prophetic act to formalize the Madina Charteris included into legal sunnah (sunnah Syar'yyah) in his capacity as a imam or head of state. According to Kamali's exploration, in my opinion, the Prophetic act to legislate the Medina Charter is included into sunnah in his capacity as imam or head of state. The clasification, therefore, causes the indication of the different legalities (mashru'iyyah).The examplery conduct of Propeht does not constitue general law (tashri' amm), but special law (tashri' khass). The implication of this type is the law may not be practised by individuals without obtaining the permission of competent government authorities first.Therefore, Muslims are not obliged to make the form of an Islamic state and form of the Islamic Constitution as the Medina Charter. People in a certain state, even the Muslim majority, may not formalize the constitution based on shari'ah without obtaining a prior aggreement of all people, i.e. represented by the People's Consultative Assembly and People's Representative Council (DPR and MPR in the Indonesian Context).

There is similar spirit of human right's protection in the Medina Charter and the Indonesian Constitution. What needs to be taken from the Medina Charter is precisely the opportunity for Indonesian Muslims to implement the spirit of human rights protection for every citizen regardless of religious background. If the spirit of human rights protection for each of these citizens has been fulfilled properly through the existence of the Indonesian Constitution, this is the same as the Indonesian Muslims have carried out the management of the country based on Islamic principles.In addition, the spirit of human rights protection that can be transformed into the Indonesian Constitution is the protection of illiberal human rights. However, the protection of human rights that puts forward the spirit of maintaining the unity and integrity of the nation (nationalism). That is why human rights protection like this will oversee the implementation of human rights which are on the path of respect for the plurality of society. Therefore, it can be concluded that without declaring an Islamic Constitution, the 1945 Constitution actually accommodates the spirit of protecting human rights which is similar to the Medina Charter.

\section{REFERENCES}

Ahmad, Zainal Abidin, Piagam Nabi Muhammad SAW: Konstitusi Negara Tertulis yang Pertama di Dunia. Jakarta: Bulan Bintang, 1973.

Ahmed,Ishtiaq., "Abdullah Ahmad an-Na'im on Constitutional and Human Rights Issues, (ed) Tore Lindholm and Kari Vogt, Islamic Law Reform and Human Rights. Oslo: the Norwegian Institute of Human Rights, 1993. 
al-Shawkani, Yahya. Irshad al-Fuhul min Tahqiq al-Haqq ila 'Ilm al-Usul. Cairo: Dar alFikhr, n.d.

an-Na'im, Abdullah Ahmad,Toward and Islamic Reformation. New York: Syracuse University Press, 1990.

Azhary,Tahir. Negara Hukum: Suatu Studi tentang Prinsio-prinsipnya Dilihat dari Segi Hukum Islam, Implementasinya pada Periode Negara Madinah dan Masa Kini, $2^{\text {nd }}$ Ed. Jakarta: Kencana, 2004.

Black, Henry C. Black's Law Dictionary, 5th Ed. St. Paul: West Publishing, 1979.

Budiardjo, Miriam. Dasar-dasar Ilmu Politik. Jakarta: PT. Gramedia Pustaka Utama, 1991.

Guillaume,A.,The Life of Muhammad, translation ofSirah Rasul Allah. Pakistan: Pakistan branch of Oxford University Press, 1970.

Hamzah, Hamzah, and Samiang Katu. "Pemikiran Islam tentang Hubungan Negara dengan Agama." Dirasat Islamiah: Jurnal Kajian Keislaman 1.1 (2020): 59-80.

Jati, Wasito Raharjo. "PermasalahanImplementasiPerda Syariah DalamOtonomi Daerah”, Jurnal Kajian Hukum Islam, Volume VII, No. 2 (July, 2013).

Kamali, Mohammad Hashim. Principles of Islamic Jurisprudence. Cambridge: The Islamic Texts Society, 2003.

Khallaf,'Abd al-Wahhab. 'Ilm Usul al-Fiqh. 12th edition. Kuwait: Dar al-Qalam, 1978).

Mahfudz MD, Moh. Membangun Politik Hukum, Menegakkan Konstitusi. Jakarta: LP3ES, 2006.

Mcllwain, C.H. Constitutionalism Ancient and Modern. Ithaca: Cornel University Press, 1947.

Shaltut, Muhammad. al-Islam, 'Aqidah wa Shari'ah. Kuwait: Matabi Dar al-Qalam, 1966.

Sukardja, Ahmad. Piagam Madinah dan Undang-Undang Dasar 1945: Kajian Perbandingan tentang Dasar Hidup Bersama dalam Masyarakat Majemuk, (Jakarta: UI-Press, 1995).

Thaib, Dahlanet al. Teori Konstitusi dan Hukum Konstitusi. Cet. V; Jakarta: PT Raja Grafindo Persada, 2005).

Watt, A Montgomery. Muhammad: Prophet and Statesman. New York: Oxford University Press, 1964.

Wheare, K. C. Modern Constitutions. London: Oxford University Press, 1966. 